\title{
ORAL ADMINISTRATION OF PIPERINE FOR THE CONTROL OF AFLATOXIN INTOXICATION IN RATS
}

\author{
Thalita B. Gagini ${ }^{1}$, Robson E. Silva ${ }^{1}$; Isabela S. Castro ${ }^{1}$, Breno A. Soares ${ }^{2}$, Marco E.F. Lima ${ }^{2}$, Marilene F. Brito ${ }^{1}$, Carlos \\ Mazur $^{1}$, Glória M. Direito ${ }^{1}$, Maria das Graças M. Danelli ${ }^{1 *}$
}

${ }^{1}$ Instituto de Veterinária, Universidade Federal Rural do Rio de Janeiro, Seropédica, RJ, Brasil; ${ }^{2}$ Instituto de Ciências Exatas, Universidade Federal Rural do Rio de Janeiro, Seropédica, RJ, Brasil.

Submitted: May 02, 2008; Returned to authors for corrections: June 10, 2008; Approved: November 07, 2009.

\begin{abstract}
Aflatoxins are mycotoxins that have important toxic effects on human and animal health, even if consumed at low doses. The oral administration of piperine $(1.12 \mathrm{mg} / \mathrm{kg})$ during 23 days in rats seemingly interfered with the toxicity of aflatoxins, decreasing hepatic injuries and the leukocyte depletion in experimentally intoxicated animals.
\end{abstract}

Key words: aflatoxins, piperine, experimental intoxication, rats.

Aflatoxins are mycotoxins produced by several Aspergillus species and widely detected in agricultural products (6). Several animal species are sensitive and acute tissue toxicity, mutagenic, carcinogenic and teratogenic effects may be included among the metabolic and genetic alterations (10). The liver is the main target and hepatic carcinogenesis is the most important effect of subacute toxicity (3). Additionally, aflatoxins interfere with immunological responses, predisposing animals to infections and parasitical diseases and decreasing vaccinal performance $(5,8)$.

Piperine (1-piperol piperidine) is an amide found in Piper species that non-specifically increases the bioavailability of several drugs and nutritional supplements, involving different P-450 cytochrome types $(2,11)$ and plays a chemoprotector role against the procarcinogenic toxicity of benzo(a)pyrene, heavy metals and aflatoxins $(9,12,13)$.

Considering that piperine can be a powerful chemopreventive agent against the activation of procarcinogens in vitro, such as aflatoxins, this research was carried out in vivo in order to evaluate whether piperine, orally supplied to rats, is able to decrease the toxic effect of aflatoxins on white blood cells and the liver.

Piperine was obtained according to Ikan's method (7), in a $5-7 \%$ yield and $98 \%$ purity, determined by GC-MS. The melting point (128-129 $\left.{ }^{\circ} \mathrm{C}\right)$ and spectrometric data $(1 \mathrm{H}$ and 13C NMR, IR and MS) identical to values reported in the literature $(1,14)$. Piperine was dissolved in $1.0 \mathrm{ml}$ DMSO/ethanol 10\% right before use. Aflatoxins were obtained from 11-day Aspergillus parasiticus CMDB 0460 NRLL 2999 cultures, in Yes culture media (Micromed) at $37^{\circ} \mathrm{C}$ and by HPLC on a normal phase system, according to DIREITO (4). After chloroform evaporation, the aflatoxin solution (containing $62.89 \%$ of AFB1 and $37.09 \%$ of AFG1) was dissolved in maize oil and vigorously homogenized in an ultrasound bath.

Piperine and aflatoxins doses were elected based on previous assays (data not shown): the oral piperine dose (1.12 $\mathrm{mg} / \mathrm{kg}$ ) confirmed the results of Dogra et al. (5), being a safe dose for mice. The $7.2 \mu \mathrm{g} / \mathrm{kg}$ aflatoxins dose was chosen based on the capability to induce hepatic alterations and white blood

*Corresponding Author. Mailing address: Universidade Federal Rural do Rio de Janeiro, Instituto de Veterinária/DMIV, Br. 465, Km 07, 23890-000, Seropédica, RJ, Brasil.; Tel: (21) 2682-1711.; E-mail: danelli@ufrrj.br 
cell reduction without causing other impairments.

The experiments were carried out using LOU-M rats, kept under standard environmental conditions, appropriately fed and given water ad libitum. The animals were randomly divided into three experimental groups $(\mathrm{n}=10)$ and orally supplied once a day, according to the following treatments: [Group 1] $200 \mu \mathrm{L}$ of piperine $(1.12 \mathrm{mg} / \mathrm{kg})$ diluted in PBS pH 7.2 and mixed v/v in maize oil for 23 days; [Group 2] $200 \mu \mathrm{L}$ of aflatoxin $(7.2 \mu \mathrm{g} / \mathrm{kg})$ mixed $\mathrm{v} / \mathrm{v}$ in maize oil for 21 days; [Group 3] $200 \mu \mathrm{L}$ of piperine $(1.12 \mathrm{mg} / \mathrm{kg})+200 \mu \mathrm{L}$ of aflatoxin $(7.2 \mu \mathrm{g} / \mathrm{kg})$; piperine were administrated for 23 days and aflatoxin were provided for 21 days, starting at the $3^{\text {rd }}$ day of inoculation with piperine.

At the end of the experiments, animal blood samples were collected by intra-cardiac puncture. Blood samples were added of EDTA and a leukogram was done. Samples not added of EDTA were submitted to aspartate aminotransferase (AST) alanine aminotransferase (ALT) determinations (Laborlab, $\mathrm{SP} /$ Brazil). The animals were euthanized in a $\mathrm{CO}_{2}$ chamber and the livers were fixed in formalin $10 \%, \mathrm{pH} 7.8$, stained with hematoxilin-eosin (HE) and processed for microscopic analysis.

The results of weight again, liver weight, enzyme dosage and leukogram profile (Table 1). Were expressed as mean \pm S.D. of ten animals in each group. The significant mean of different parameters between treatment groups was analysed using one-way analysis of variance (ANOVA) after ascertaining the homogeneity of variance between treatments. The difference was considered statistically significant when $\mathrm{p}<0.05$.

Table 1. Influence of piperine on average weight gain, average liver weight, enzyme dosage and leukogram profile.

\begin{tabular}{|c|c|c|c|}
\hline \multirow[b]{2}{*}{ Parameters } & \multicolumn{3}{|c|}{ Groups } \\
\hline & $\begin{array}{c}\text { Piperine } \\
(1.12 \mathrm{mg} / \mathrm{kg})\end{array}$ & $\begin{array}{c}\text { Aflatoxin } \\
(7.2 \mu \mathrm{g} / \mathrm{kg})\end{array}$ & Piperine + Aflatoxin \\
\hline Viability (\%) & 100 & 100 & 100 \\
\hline Weight gain ${ }^{1}(\mathrm{mg} / \mathrm{kg})$ & $56.67^{\mathrm{a}} \pm 6$ & $51.20^{\mathrm{a}} \pm 10.08$ & $55.40^{\mathrm{a}} \pm 6.638$ \\
\hline Liver weight $^{2}(\mathrm{mg} / 100 \mathrm{~g})$ & $4.394^{\mathrm{a}} \pm 0.246$ & $4.303^{\mathrm{a}} \pm 0.264$ & $4.574^{\mathrm{a}} \pm 0.291$ \\
\hline $\operatorname{ALT}^{3}(\mathrm{UI} / \mathrm{L})$ & $41.80^{\mathrm{a}} \pm 12.89$ & $65.45^{b} \pm 10.58$ & $30.20^{\mathrm{c}} \pm 11.20$ \\
\hline \multicolumn{4}{|l|}{$(26-37)^{*}$} \\
\hline $\operatorname{AST}^{4}(\mathrm{U} / \mathrm{l})$ & $44.50^{\mathrm{a}} \pm 21.45$ & $58.09^{\mathrm{a}} \pm 17.86$ & $50.90^{\mathrm{a}} \pm 22.92$ \\
\hline \multicolumn{4}{|l|}{$(40-53)^{*}$} \\
\hline $\mathrm{WBC}^{5}\left(\mathrm{x} 10^{3} / \mathrm{mm}^{3}\right)$ & $10.48^{\mathrm{a}} \pm 2.161$ & $8.108^{b} 1.732$ & $10.92^{\mathrm{a}} \pm 2.279$ \\
\hline \multicolumn{4}{|l|}{$(7.30-12.66)^{*}$} \\
\hline Lymphocytes $\left(\times 10^{3} / \mathrm{mm}^{3}\right)$ & $8.798^{a} \pm 1.981$ & $6.477^{\mathrm{b}} \pm 1.409$ & $9.012^{\mathrm{a}} \pm 2.085$ \\
\hline \multicolumn{4}{|l|}{$(5.07-9.07)^{*}$} \\
\hline Neutrophils $\left(\times 10^{3} / \mathrm{mm}^{3}\right)$ & $0.659^{\mathrm{a}} \pm 0.304$ & $0.531^{\mathrm{a}} \pm 0.038$ & $0.604^{\mathrm{a}} \pm 0.414$ \\
\hline \multicolumn{4}{|l|}{$(1.25-3,71)^{*}$} \\
\hline Monocytes $\left(\mathrm{x} 10^{3} / \mathrm{mm}^{3}\right)$ & $0.796^{\mathrm{a}} \pm 0.229$ & $0.793^{a} \pm 0.802$ & $1.045^{\mathrm{a}} \pm 0.343$ \\
\hline \multicolumn{4}{|l|}{$(0.50-0.74)^{*}$} \\
\hline Eosinophils $\left(\times 10^{3} / \mathrm{mm}^{3}\right)$ & $0.297^{\mathrm{a}} \pm 0.111$ & $0.302^{\mathrm{a}} \pm 0.177$ & $0.259^{\mathrm{a}} \pm 0.243$ \\
\hline$(0.04-0.30)^{*}$ & & & \\
\hline
\end{tabular}

Data are expressed by the group \pm standard deviation for 10 animals. Statistical analysis made by variance analysis; ${ }^{1} \mathrm{mg} / \mathrm{kg}$ of body weight; ${ }^{2} \mathrm{mg} / 100 \mathrm{~g}$ of body weight; ${ }^{3}$ alanine aminotransferase; ${ }^{4}$ aspartate aminotransferase; ${ }^{5}$ white blood cells; $*$ reference values interval /Thrall et al. (15). ${ }^{\mathrm{a}, \mathrm{b}}$ different letters mean significant differences $(\mathrm{p}<0.05)$. 
Orally administered aflatoxins caused alterations in the plasma enzyme dosage and leukogram. The increase in ALT plasmatic levels (1.8 times higher than the upper limit of the reference interval) was mild but statistically significant $(\mathrm{p}<0.05)$, in comparison to groups that received piperine (Group1) and piperine plus aflatoxin (Group 2). The same was not observed in AST levels, which remained within the reference interval (Table 1). These results suggest that 7.2 $\mu \mathrm{g} / \mathrm{kg}$ of aflatoxin orally inoculated once a day, for 21 days, caused plasmatic membrane injuries in hepatocytes of rats. Table 2 shows the histopathological lesions observed in livers of rats, ranging from minor to intense, consistent with histopathological injuries caused by aflatoxin intoxication (10). The Aflatoxin group leukogram showed discreet leukopenia and lymphopenia within the reference interval, which were significant $(\mathrm{p}<0.05)$ when compared to the other groups (Table $1)$.

Piperine orally supplied with aflatoxins produced a remarkable decrease $(\mathrm{p}<0.05)$ in hepatic injuries (Table 2$)$ and impaired the toxic effect of the aflatoxin on white blood cells (Table 1). These results suggest that piperine, orally administrated at a $1.12 \mathrm{mg} / \mathrm{kg}$ dose, can decrease the toxic effects of aflatoxins at $7.2 \mu \mathrm{g} / \mathrm{kg}$ doses.

These preliminary results support new in vivo studies, showing that piperine can prevent the suppression of leukocytes and reduce the toxicity of aflatoxins in tissues, as already observed in vitro (12). It is a potential in vivo chemical preventive agent against the toxicity of aflatoxins.

Table 2. Histopathological lesions observed in livers of rats

\begin{tabular}{lccc}
\hline \multicolumn{1}{c}{$\begin{array}{c}\text { Histopathological } \\
\text { Injuries }\end{array}$} & \multicolumn{3}{c}{ Lesion Degree $^{\mathbf{1}}$} \\
\cline { 2 - 4 } & Piperine & Aflatoxin & P + A \\
\hline Megalocytosis & $(+)$ & +++ & + \\
Individual cell necrosis & - & $+(+)$ & + \\
Hepatocytes with vacuoles & - & $++^{\mathrm{F}}$ & - \\
Mononuclear cell infiltrate regions & $(+)$ & $(+)$ & +() \\
Necrosis in hepatocytes & - & + & - \\
Centrilobular to paracentral necrosis & - & +++ & - \\
Centrilobular congestion & - & ++ & - \\
\hline
\end{tabular}

${ }^{1}$ Lesions observed in the majority of the animals: no lesion [-]; discreet $[(+)]$; light $[+]$; light to moderate $[+(+)]$; moderate $[++]$; marked [+++].

${ }^{\mathrm{F}}$ Lesions in focus.

\section{ACKNOWLEDGMENTS}

To Conselho Nacional de Desenvolvimento Científico e Tecnológico - CNPq, Brazil.

\section{REFERENCES}

1. Araujo-Junior, J. X. Emidio, V.L., Da-Cunha, M.C.O.C., Gray, A.I. (1997). Piperdardin, a piperidine alkaloid from Piper tuberculatum. Phytochemistry, 44, 559-561.
2. Atal, C. K., Dubey, R.K., Singh, J. (1985). Biochemical basis of enhanced drug bioavailability by piperine: evidence that piperine is a potent inhibitor of drug metabolism. J. Pharmacol. Exp. Therap. 232, 258-262.

3. Creppy, E., Castegnaro, M., Dirheimer, G. (1993). Human Ochratoxicosis and its Patologies in France. Colloque Inserm, Montroge, France, v. 231

4. Direito, G.M. (1989). Desenvolvimento de fase móvel para separação de aflatoxinas por cromatografia líquida de alta eficiência utilizando fase normal em sistemas de compressão radial. Rio de Janeiro, Brazil, 132p. (M.Sc. Dissertation. Instituto de Microbiologia. UFRRJ). 
5. Dogra, R.K., Khanna, S., Shanker, R. (2004). Immunotoxicological effects of piperine in mice. Toxicology. 196, 229-36.

6. Iamanaka, B.T., Menezes, H. C., Vicente, E., Leite, R.S.F., Taniwaki, M.H. (2007).Aflatoxigenic fungi and aflatoxins occurrence in sultanas and dried figs commercialized in Brazil. Food Control, 18, p. 454-45,

7. Ikan, R. (1991). In natural products. A laboratory guide. Academic Press. New York, USA.

8. Moon, E.Y., Rhee, D.K., Pyo, S. (1999). Inhibition of various functions in murine peritonela macrophages by aflatoxin B1 exposure in vivo. International J. Immunopharmacol. 21, 47-58.

9. Pathak, N.; Khandelwal, S. (2007). Cytoprotective and immunomodulating properties of piperine on murine splenocytes: an in vitro study. Eur. J. Pharmacol. 576, 160-170.

10. Pier, A.C.; Cysensky, S.L.J.; Richard, J.L. (1997). Mycotoxins as a veterinary problem. In: Rodricks, J.V., Hesseltine, C.W.L., Mehlman, M. (eds). Mycotoxins in human and animal health. Pathox Publishers, p. $745-750$.
11. Reen, R.K. (1996).Piperine impairs cytochrome P4501A1 activity by direct interaction with the enzyme and not by down regulation of CYP1A1 gene expression in the rat hepatoma 5L cell line. Biochem. Bioph. Res. Comm. 218, 562-569.

12. Reen, R.K., Fruedrich, J., Wiebel, B., Singh, J. (1997). Piperine inhibits aflatoxin B1-induced cytotoxicity and genotoxicity in V79 Chinese hamster cels genetically engineered to express rat cytochrome P4502B1. J. Ethnopharmacology. 58, 165-173.

13. Selvendiran, K.; Banu, S.M.; Sakthisekaran, D. (2005). Oral supplematation of piperine leads to altered phase II enzymes and reduced DNA damage and DNA-protein cross links in benzo $(a)$ pyrene induced experimaental lung carcinogenesis. Mol. Cell Biochem., 26, 141-147.

14. Siddiqui, B.S., Begum S., Tahsin, G., Farhat, F. N. (1997). An amide from fruits of Piper nigrum. Phytochemistry, 45, 1617-1619.

15. Thrall, M.A.; Baker, D.C.; Campbell, T.W.; DeNicola, D.; Fettman, M.J.; Lassen, E.D.; Rebar, A.; Weiser, G. (2007). Hematologia e Bioquímica Clínica Veterinária. Roca Press, SP, Brazil. 